\title{
GAMBARAN TINGKAT PENGETAHUAN DAN SIKAP MASYARAKAT TENTANG PENCABUTAN GIGI DI DESA MOLOMPAR UTARA KABUPATEN MINAHASA TENGGARA
}

\author{
${ }^{1}$ Bayu R E Warouw \\ ${ }^{2}$ A. J. M. Rattu \\ ${ }^{3}$ Ni Wayan Mariati
}

\author{
${ }^{1}$ Kandidat Skripsi Program Studi Pendidikan Dokter Gigi Fakultas Kedokteran Universitas \\ Sam Ratulangi Manado \\ ${ }^{2}$ Fakultas Kesehatan Masyarakat Universitas Sam Ratulangi Manadk \\ ${ }^{3}$ Program Studi Pendidikan Dokter Gigi Fakultas Kedokteran \\ Universitas Sam Ratulangi Manado \\ E-mail: erickwarouw@ymail.com
}

\begin{abstract}
Tooth extraction is a mostly performed treatment in dental practice because most patients come with bad tooth condition that cannot be taken care anymore. The obstacle of tooth extraction is the society's knowledge. Lack of knowledge causes doubt about going to the dentist. This study aimed to determine the overview of the knowledge and attitude levels of the people in North Molompar Village, South East Minahasa about tooth extraction. This was a descriptive study with a cross sectional design. There were 87 samples obtained by using the Slovin formula with random sampling method. Data presented in the form of a diagram based at the frequency distribution. The results showed that the knowledge level of tooth extraction in North Molompar was 55\% good, obtained from scoring result of 481, and the attitude level of tooth extraction was $69 \%$ good, obtained from scoring result of 604 . Conclusion: Levels of knowledge and attitude of the people in North Molompar Village, South East Minahasa, about tooth extraction were categorized as good.
\end{abstract}

Keywords: tooth extraction, knowledge, attitude.

\begin{abstract}
Abstrak: Pencabutan gigi merupakan tindakan yang sering dilakukan dalam praktek kedokteran gigi karena kebanyakan pasien datang dengan keadaan gigi yang sudah tidak bisa dirawat lagi. Hambatan yang dialami dalam upaya pencabutan gigi ialah pengetahuan masyarakat mengenai hal-hal yang menyangkut pencabutan gigi. Pengetahuan yang kurang memadai membuat masyarakat ragu untuk berobat ke dokter gigi. Penelitian ini bertujuan untuk mengetahui gambaran tingkat pengetahuan dan sikap masyarakat tentang pencabutan gigi di Desa Molompar Utara Kabupaten Minahasa Tenggara. Penelitian ini bersifat deskriptif dengan desain potong lintang. Jumlah sampel sebanyak 87 responden diperoleh dengan menggunakan rumus Slovin dan penarikan sampel berupa acak sederhana. Data disajikan dalam bentuk diagram berdasarkan distribusi frekuensi. Hasil penelitian menunjukkan tingkat pengetahuan masyarakat tentang pencabutan gigi di Desa Molompar Utara yaitu 55\% dapat dikatakan baik (hasil skoring 481) dan sikap masyarakat tentang pencabutan gigi di yaitu 69\% dapat dikatakan baik (hasil skoring 604). Simpulan: Tingkat pengetahuan dan sikap masyarakat di Desa Molompar Utara terhadap pencabutan gigi tergolong baik.
\end{abstract}

Kata kunci: pencabutan gigi, pengetahuan, sikap. 
Ilmu kesehatan berkembang dari pengetahuan yang diketahui oleh manusia. Pengetahuan dapat diperoleh dari berbagai sumber antara lain pancaindera, pikiran, dan intuisi. Bila dibandingkan antara pengetahuan dan ilmu pengetahuan terdapat perbedaan yang nyata. Pengetahuan ialah semua yang diketahui oleh manusia tanpa memperhatikan pengetahuan tersebut benar atau salah, sedangkan ilmu pengetahuan membatasi pengetahuan yang benar saja.

Pengetahuan yang benar adalah pengetahuan yang telah teruji kebenarannya melalui metode ilmiah. Manusia ingin terbebas dari penyakit, maka mereka mulai mempelajari atau mengkaji bagaimana caranya agar manusia dapat selalu hidup sehat. Dengan menggunakan kemampuan berpikir rasional atas dasar pengetahuan, menarik minat orang untuk mempelajari ilmu kesehatan yang kemudian kita kenal sebagai ahli ilmu kesehatan. ${ }^{1}$

Pelayanan kesehatan gigi dan mulut sebagai dari pelayanan kesehatan secara umum juga tidak terlepas dari upaya peningkatan mutu kesehatan. Berbicara masalah kesehatan secara umum, tidak terlepas dari masalah kesehatan gigi khususnya. Kesehatan gigi sebagai bagian integral dari kesehatan umum perlu mendapat perhatian dari pemerintah maupun masyarakat. $^{2}$

Pencabutan gigi adalah menghilangkan gigi. Jika saraf gigi telah mati atau gigi telah terinfeksi sangat parah, pencabutan merupakan satu-satunya cara. Pencabutan gigi bisa dilakukan dengan cara yang sederhana ataupun pencabutan yang rumit. Faktor penyebab paling sering untuk kasus pencabutan gigi yaitu gigi berlubang yang sudah sangat parah dan tidak bisa dirawat lagi. ${ }^{3}$

Kondisi ini menggambarkan bahwa pelayanan kesehatan gigi baru ditangani pada kondisi penyakit yang sudah dalam keadaan parah. Dengan demikian, upaya pemberian pelayanan kesehatan gigi pada masyarakat berupa pencabutan gigi kadang mengalami hambatan yang besar. Umumnya hambatan yang terjadi karena pengetahuan masyarakat terhadap tindakan pencabutan gigi sangat kurang, hal inilah yang masih mempengaruhi sikap sebagian masyarakat. ${ }^{5}$

Perilaku masyarakat pedesaan dan perkotaan terhadap penyakit gigi dan mulut berbeda. Ketika masyarakat di desa mengalami masalah gigi dan mulut, mereka masih menggunakan cara tradisional sesuai dengan pengetahuan dan pengalaman sendiri, atau dengan bantuan orang lain yang bukan berprofesi sebagai dokter gigi. Sebaliknya masyarakat perkotaan selalu berkonsultasi dengan dokter gigi ketika mengalami gangguan pada gigi dan mulut, karena pengetahuan mereka tentang kesehatan gigi dan mulut sudah lebih luas. ${ }^{6}$

Pentingnya pengetahuan dan sikap masyarakat tentang pencabutan gigi sebagai upaya peningkatan kesehatan gigi dan mulut di masyarakat, serta belum adanya fasilitas kesehatan yang memadai seperti yang ada di kota-kota berkembang hal inilah yang membedakan masyarakat yang ada di Kota dan di Desa sehingga mempengaruhi sikap dari masyarakat pedesaan. Melihat masalah ini belum pernah dilakukan penelitian di Desa Molompar Utara Kabupaten Minahasa Tenggara, maka peneliti tertarik untuk melakukan penelitian.

Tujuan dari penelitian ini ialah untuk mengetahui tingkat pengetahuan dan sikap masyarakat tentang pencabutan gigi di Desa Molompar Utara.

\section{BAHAN DAN METODE}

Penelitian ini merupakan penelitian deskriptif dengan desain penelitian potong lintang. Besar sampel yang diteliti berjumlah 87 responden diperoleh dengan menggunakan rumus Slovin.

Penelitian dilakukan dengan terlebih dahulu meminta izin pada kepala Desa setempat untuk dilakukan penelitian pada masyarakat. Pengambilan data dilakukan dengan menggunakan kuesioner yang diisi oleh masyarakat yang akan dijadikan sampel dimintakan izin tertulis berupa informed consent. Setelah mendapat izin dari masyarakat maka pelaksanaan penelitian dimulai.

Data yang diperoleh dengan teknik membagikan kuesioner secara langsung kepada responden sebanyak 87 orang yang tersebar diseluruh Desa Molompar Utara. Dilakukan secara acak kemudian dipilih berdasarkan kriteria inklusi dan ekslusi. Setelah sampel didapat maka pengisian kuesioner dimulai. 
Data diolah berdasarkan distribusi frekuensi dan disajikan dalam bentuk diagram kemudian dianalisis secara deskriptif berdasarkan hasil persentase. Kriteria penilaian menggunakan skala Guttman.

\section{HASIL PENELITIAN}

\section{Karakteristik Subjek Penelitian}

Subjek berdasarkan distribusi karakteristik jenis kelamin dapat dilihat pada Gambar 3 di bawah ini.

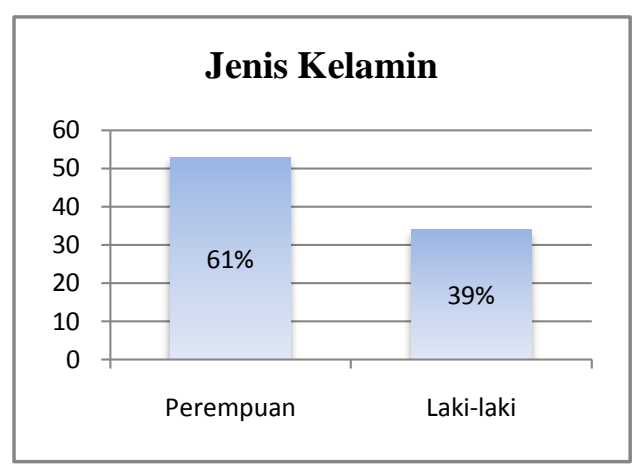

Gambar 3. Distribusi karakteristik subjek berdasarkan jenis kelamin.

Gambar 3 menunjukkan bahwa karakteristik subjek penelitian berdasarkan jenis kelamin dari 87 orang terdiri dari 53 orang perempuan (61\%) dan 34 orang lakilaki (39\%).

Sampel pada penelitian ini yaitu penduduk yang berusia 17-60 tahun yang terdaftar sebagai penduduk di desa Molompar. Karakterisitik subjek penelitian berdasarkan usia dapat dilihat pada Gambar 4 berikut ini.

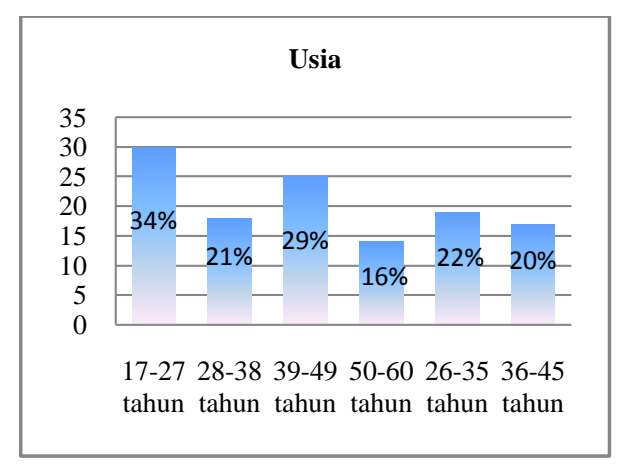

Gambar 4. Distribusi karakteristik subjek berdasarkan usia.

Gambar 4 menunjukan karakteristik subjek penelitian berdasarkan usia terdiri dari 30 orang berusia 17-27 tahun (34\%), 18 orang berusia $28-38$ tahun (21\%), 25 orang 39-49 tahun (29\%), 14 orang berusia 50-60 tahun (16\%), 19 orang berusia dewasa muda 26-35 tahun (22\%) dan 17 orang dewasa tua 36-45 tahun (20\%).

\section{Pengetahuan Responden}

Berdasarkan hasil penelitian yang didapatkan, pengetahuan responden tentang pencabutan gigi di desa Molompar Utara Kabupaten Minahasa Tenggara yaitu 55\% yang dapat dikatakan baik yang didapatkan dari hasil skoring 481 .

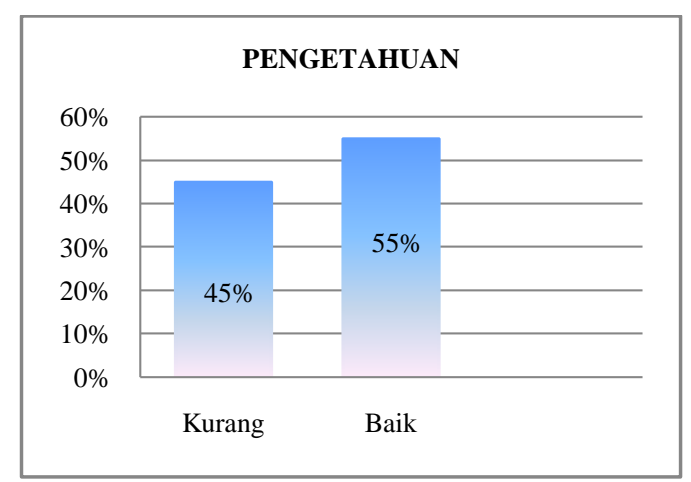

Gambar 5. Distribusi karakteristik subjek hasil penelitian tentang Pengetahuan tentang pencabutan gigi.

Pengetahuan masyarakat diukur dengan bantuan kuesioner yang terdiri dari 10 pertanyaan. Hasil penelitian dijabarkan menurut pertanyaan berikut ini:

a. Distribusi frekuensi berdasarkan pertanyaan nomor 1 (pemeriksaan kesehatan gigi dan mulut ke dokter gigi/puskesmas secara rutin 6 bulan sekali) 


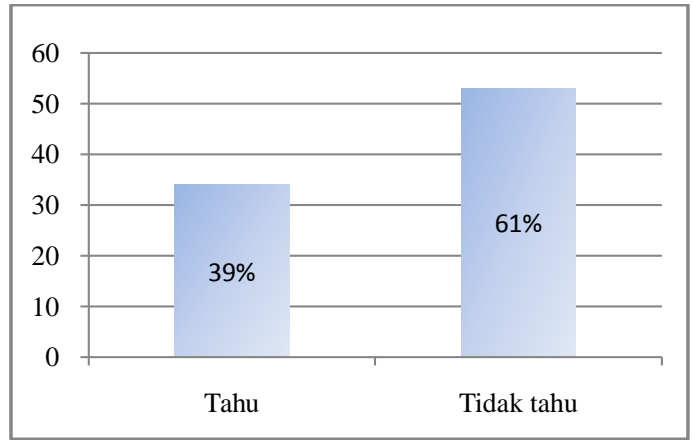

Gambar 6. Distribusi frekuensi berdasarkan pertanyaan nomor 1 .

Berdasarkan gambar 6 terlihat presentase tertinggi yaitu $61 \%$ atau 53 responden tidak tahu tentang pemeriksaan kesehatan gigi dan mulut rutin setiap 6 bulan sekali ke dokter gigi/puskesmas.

b. Distribusi frekuensi berdasarkan pertanyaan nomor 2 (pencabutan gigi tidak boleh bagi penderita penyakit jantung)

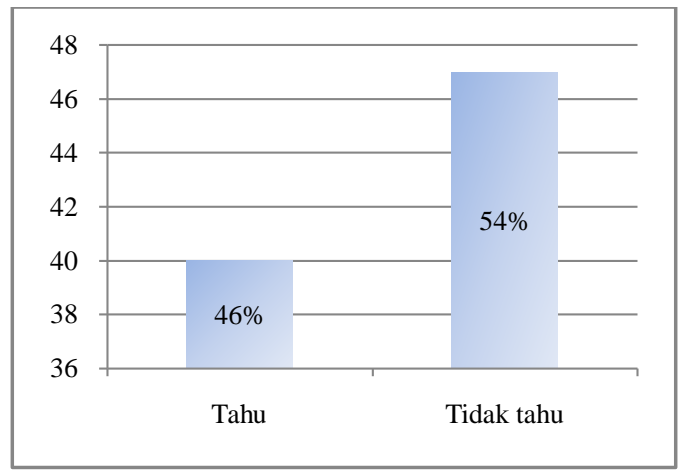

Gambar 7. Distribusi frekuensi berdasarkan pertanyaan nomor 2.

Gambar 7 menunjukan responden yang mengetahui bahwa pencabutan gigi tidak boleh bagi penderita penyakit jantung yaitu 40 responden 46\%. Sedangkan responden yang tidak mengetahui berjumlah 47 atau $54 \%$.

c. Distribusi frekuensi berdasarkan pertanyaan nomor 3 (pencabutan gigi tidak boleh bagi penderita penyakit gula)

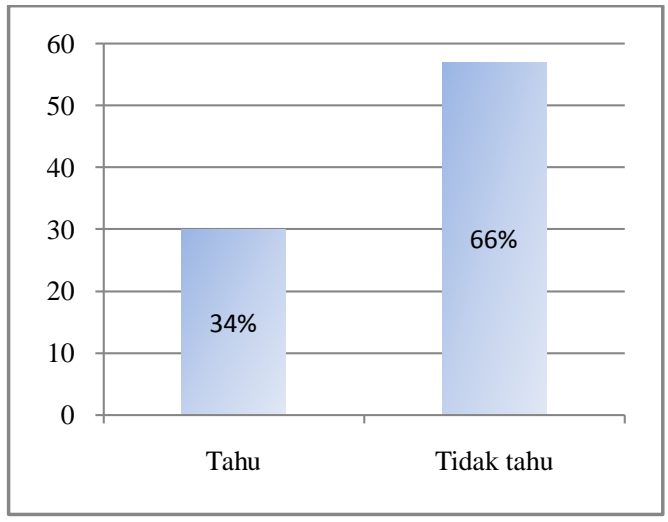

Gambar 8. Distribusi frekuensi berdasarkan pertanyaan nomor 3 .

Berdasarkan gambar 8 terlihat 66\% atau 57 responden tidak mengetahui bahwa pencabutan gigi tidak boleh bagi penderita penyakit gula (diabetes melitus).

d. Distribusi frekuensi berdasarkan pertanyaan nomor 4 (pencabutan gigi tidak boleh bagi penderita darah tinggi)

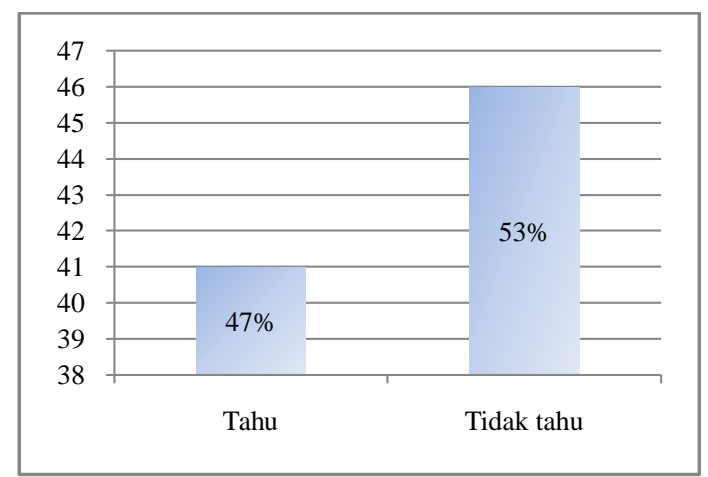

Gambar 9. Distribusi frekuensi berdasarkan pertanyaan nomor 4 .

Gambar 9 menunjukan persentase responden yang mengetahui yaitu $47 \%$ atau 41 respoden mengenai pencabutan gigi tidak boleh bagi penderita darah tinggi (hipertensi). Sedangkan responden yang menjawab tidak tahu yaitu 53\% atau 46 responden.

e. Distribusi frekuensi berdasarkan pertanyaan nomor 5 (perawatan dengan menggunakan gigi palsu setelah pencabutan gigi) 


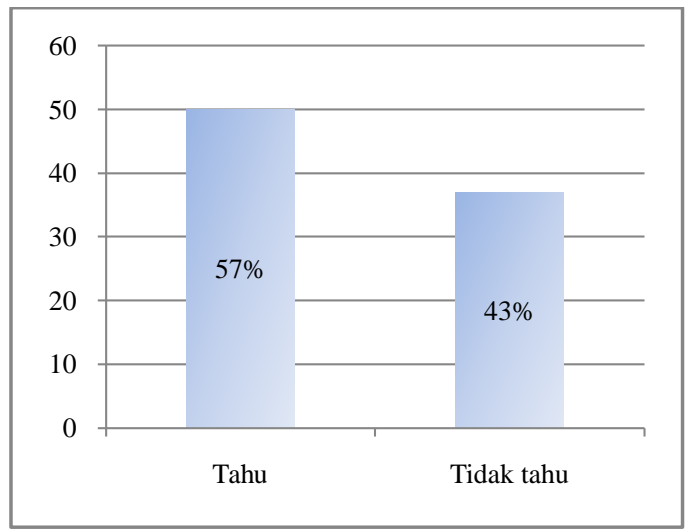

Gambar 10. Distribusi frekuensi berdasarkan pertanyaan nomor 5 .

Berdasarkan gambar 10 menunjukan bahwa yang menjawab tahu sejumlah 57\% atau 50 responden yang mengetahui perawatan dengan menggunakan gigi palsu setelah pencabutan gigi dan sisanya ada 37 responden atau $43 \%$ yang menjawab tidak tahu.

f. Distribusi frekuensi berdasarkan pertanyaan nomor 6 (pencabutan dengan operasi pada gigi geraham yang sangat miring)

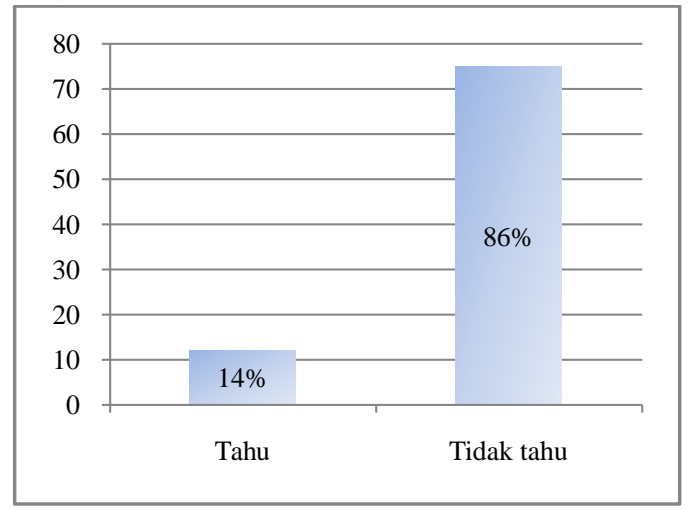

Gambar 11. Distribusi frekuensi berdasarkan pertanyaan nomor 6 .

Gambar 11 menunjukkan persentase paling tinggi menjawab tidak tahu tentang pencabutan gigi geraham miring dengan cara operasi berjumlah 75 responden $86 \%$, sedangkan persentase terendah yaitu 14\% atau 12 responden yang menjawab tahu.

g. Distribusi frekuensi berdasarkan pertanyaan nomor 7 (pencabutan gigi yang rusak lebih baik dari pada membiarkannya)

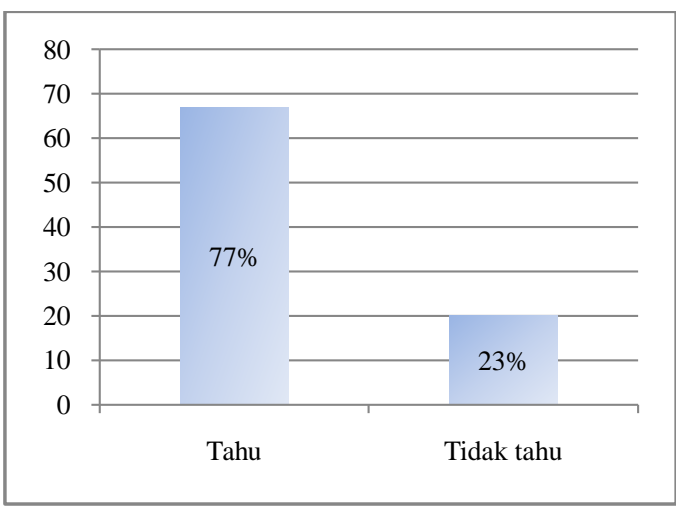

Gambar 12. Distribusi frekuensi berdasarkan pertanyaan nomor 7 .

Berdasarkan gambar 12 menunjukan bahwa $77 \%$ atau 67 responden yang menjawab tahu dan $23 \%$ atau 20 responden yang menjawab tidak tahu.

h. Distribusi frekuensi berdasarkan pertanyaan nomor 8 (pencabutan gigi membantu menjaga kesehatan mulut)

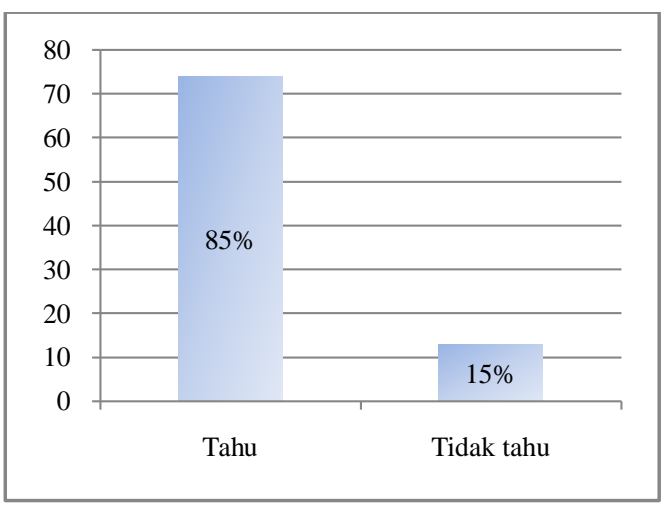

Gambar 13. Distribusi frekuensi berdasarkan pertanyaan nomor 8 .

Gambar 13 menunjukan persentase tertinggi berjumlah $85 \%$ atau 74 responden yang menjawab tahu tentang pencabutan gigi membantu menjaga kesehatan mulut, sedangkan 15\% atau 13 responden menjawab tidak tahu.

i. Distribusi frekuensi berdasarkan pertanyaan nomor 9 (meskipun pencabutan gigi agak susah, akan tetapi biayanya relatif murah) 


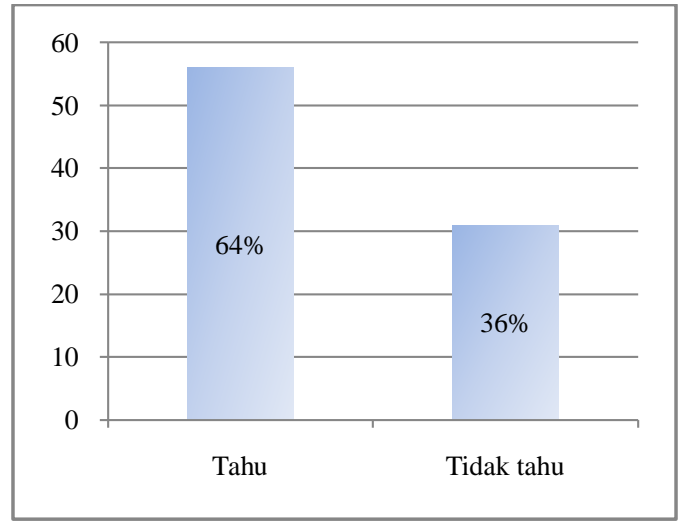

Gambar 14. Distribusi frekuensi berdasarkan pertanyaan nomor 9 .

Berdasarkan gambar 14 yang menjawab tahu berjumlah $64 \%$ atau 56 responden sedangkan yang menjawab tidak tahu berjumlah 31 responden atau $36 \%$.

j. Distribusi frekuensi berdasarkan pertanyaan nomor 10 (anda yakin untuk pencabutan gigi lebih baik ke Puskesmas dari pada menggunakan cara tradisional)

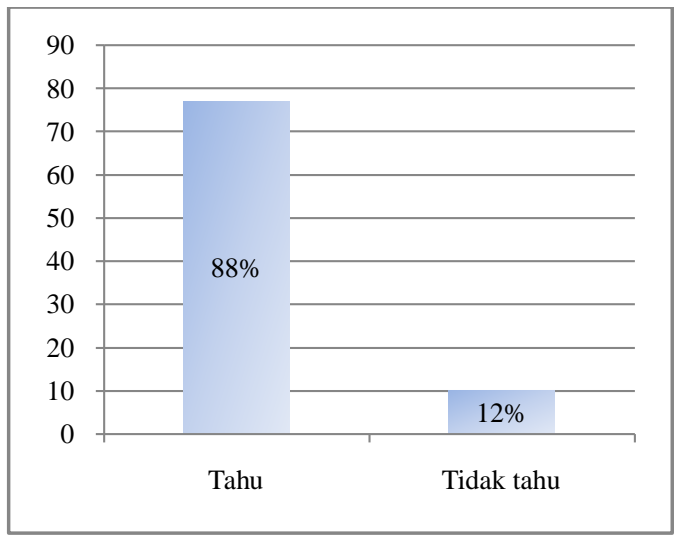

Gambar 15. Distribusi frekuensi berdasarkan pertanyaan nomor 10.

Gambar 15 menunjukan persentase tertinggi yaitu $88 \%$ atau sebanyak 77 responden yang menjawab tahu untuk pencabutan gigi lebih baik ke Puskesmas dari pada menggunakan cara tradisional sedangkan yang menjawab tidak tahu berjumlah 10 responden atau $12 \%$.

\section{Sikap Responden}

Data hasil penelitian tentang sikap responden tentang pencabutan gigi di desa Molompar Utara Kabupaten
Minahasa Tenggara yaitu 69\% yang dapat dikatakan baik diperoleh dari hasil skoring 604.

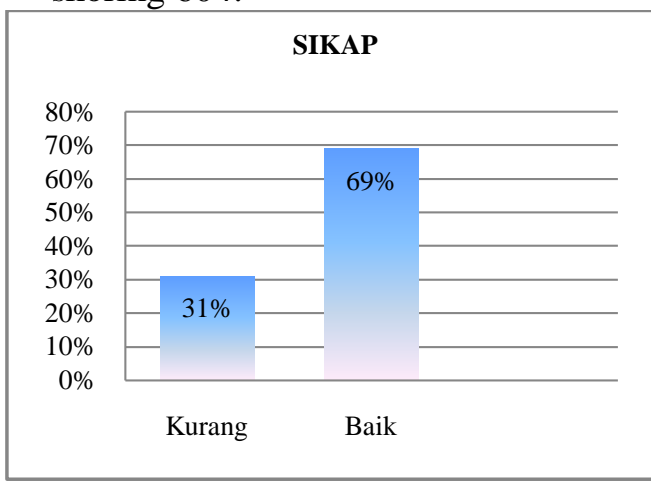

Gambar 16. Distribusi karakteristik subjek hasil penelitian tentang sikap tentang pencabutan gigi.

Sikap masyarakat diukur dengan bantuan kuesioner yang terdiri dari 10 pertanyaan. Hasil penelitian dijabarkan menurut pertanyaan berikut ini:

a. Distribusi frekuensi berdasarkan pertanyaan nomor 1 (responden merasa takut dan cemas ketika gigi dicabut)

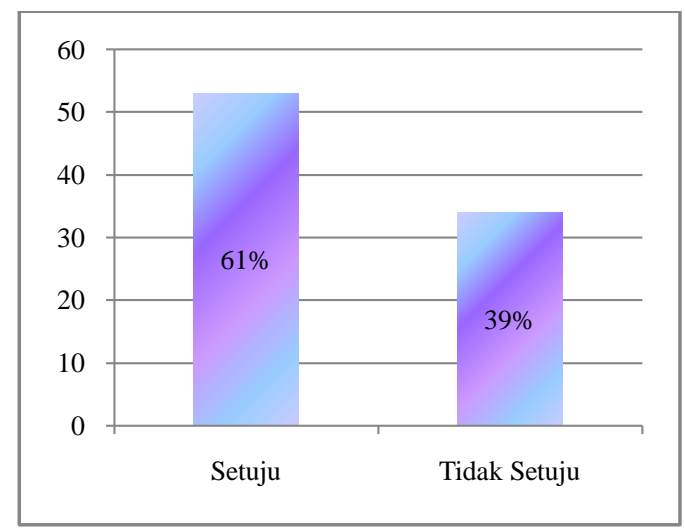

Gambar 17. Distribusi frekuensi berdasarkan pertanyaan nomor 1 .

Berdasarkan gambar 17 terlihat $61 \%$ atau 53 responden menjawab setuju dan yang menjawab tidak setuju yaitu $39 \%$ atau 34 responden.

b. Distribusi frekuensi berdasarkan pertanyaan nomor 2 (responden akan pergi ke dokter gigi/puskesmas apabila gigi berlubang) 


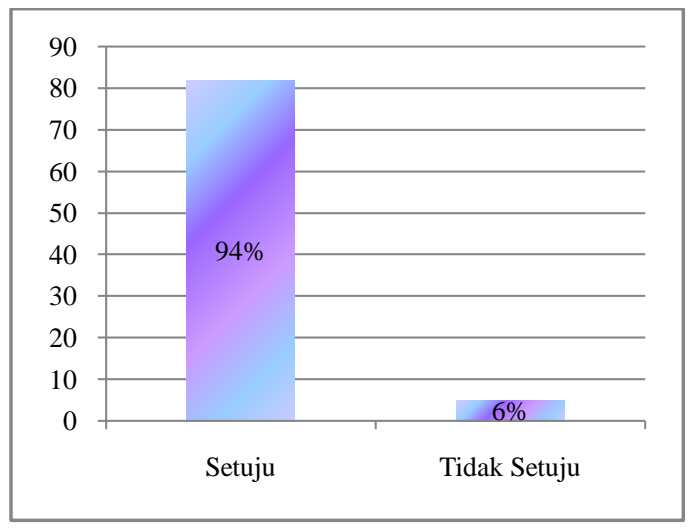

Gambar 18. Distribusi frekuensi berdasarkan pertanyaan nomor 2.

Gambar 18 menunjukan persentase tertinggi dengan menjawab setuju yaitu $94 \%$ atau 82 responden apabila gigi berlubang akan pergi ke dokter gigi/puskesmas.

c. Distribusi frekuensi berdasarkan pertanyaan nomor 3 (responden merasa malu apabila gigi rusak dan terlihat lawan bicara)

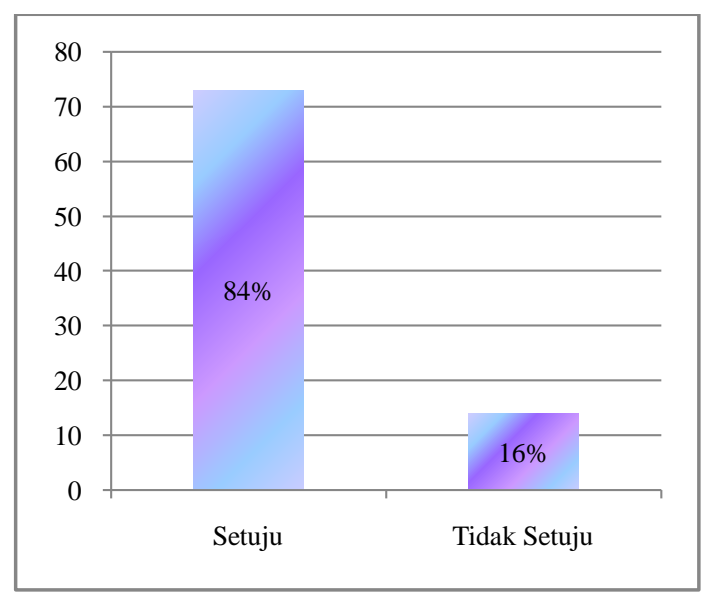

Gambar 19. Distribusi frekuensi berdasarkan pertanyaan nomor 3

Berdasarkan gambar 19 terlihat 84\% atau 73 responden setuju dengan perasaan malu ketika gigi yang rusak terlihat oleh lawan bicara sedangkan $16 \%$ atau 14 orang menjawab tidak setuju.

d. Distribusi frekuensi berdasarkan pertanyaan nomor 4 (responden akan mempertimbangkan pendapat orang sekeliling mengenai pencabutan gigi)

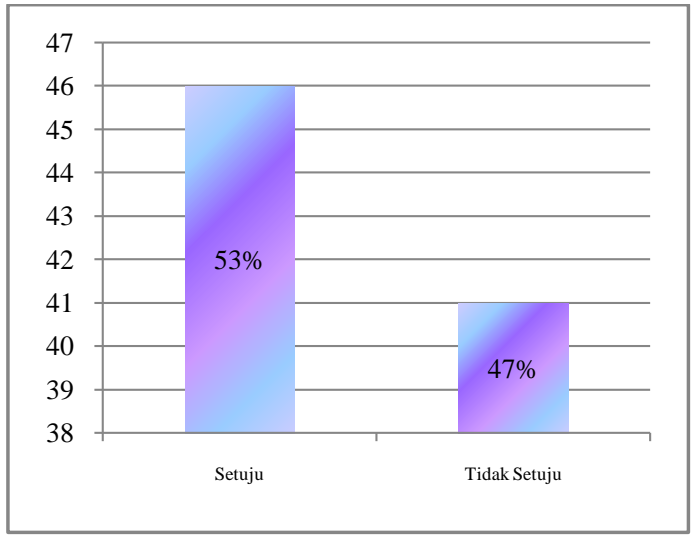

Gambar 20. Distribusi frekuensi berdasarkan pertanyaan nomor 4

Gambar 20 menunjukan responden yang tidak setuju yaitu $47 \%$ atau 41 responden apabila mempertimbangkan pendapat orang sekeliling mengenai pencabutan gigi sedangkan 53\% menjawab setuju.

e. Distribusi frekuensi berdasarkan pertanyaan nomor 5 (responden menginginkan gigi yang rusak segera dicabut saat berkunjung ke dokter gigi/puskesmas)

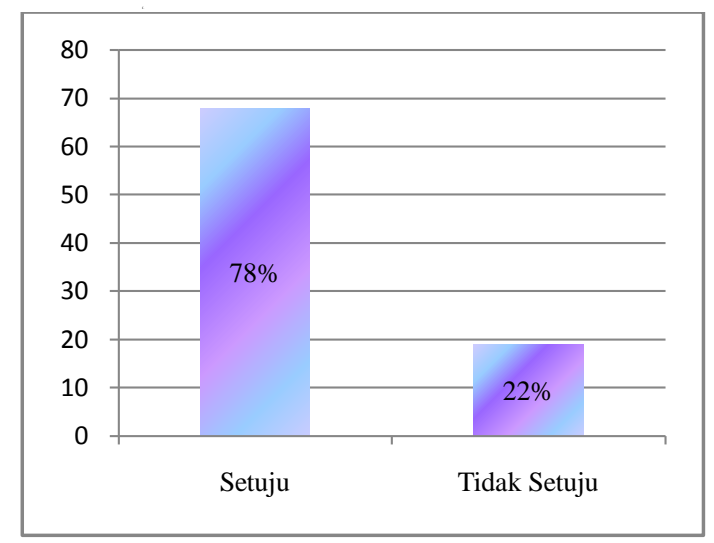

Gambar 21. Distribusi frekuensi berdasarkan pertanyaan nomor 5

Berdasarkan gambar 21 yang menjawab setuju yaitu 68 responden atau $78 \%$ jika berkunjung ke dokter gigi/puskesmas yang di inginkan ialah gigi yang rusak segera dicabut dan 22\% responden menjawab tidak setuju.

f. Distribusi frekuensi berdasarkan pertanyaan nomor 6 (responden akan menyerahkan kepada dokter gigi untuk memilih jenis pencabutan gigi) 


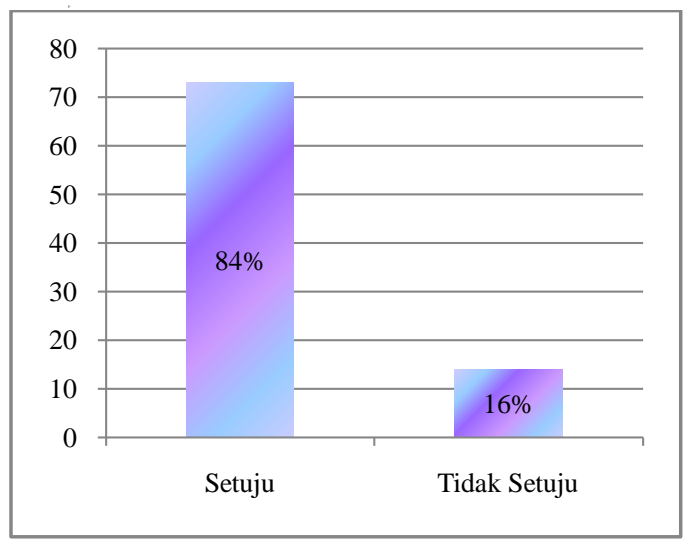

Gambar 22. Distribusi frekuensi berdasarkan pertanyaan nomor 6

Gambar 22 menunjukan responden yang setuju bahwa akan menyerahkan kepada dokter gigi untuk memilih jenis pencabutan gigi yaitu $84 \%$ atau 73 responden. Responden yang tidak setuju berjumlah $16 \%$ atau 14 orang.

g. Distribusi frekuensi berdasarkan pertanyaan nomor 7 (responden merasa sangat sehat dan nyaman apabila gigi telah dicabut)

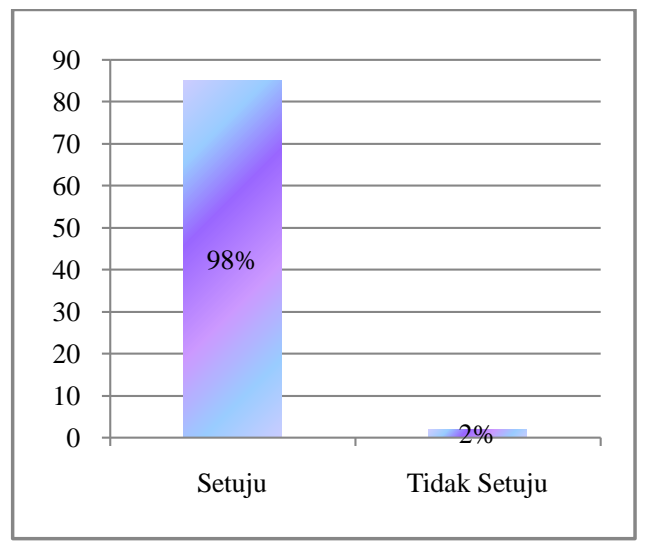

Gambar 23. Distribusi frekuensi berdasarkan pertanyaan nomor 7

Berdasarkan gambar 23 terlihat 98\% atau 85 responden menjawab setuju merasa sangat sehat dan nyaman apabila gigi telah dicabut sedangkan sisanya $2 \%$ menjawab tidak setuju.

h. Distribusi frekuensi berdasarkan pertanyaan nomor 8 (responden merasa tegang atau takut apabila melihat peralatan pada ruang praktek dokter gigi)

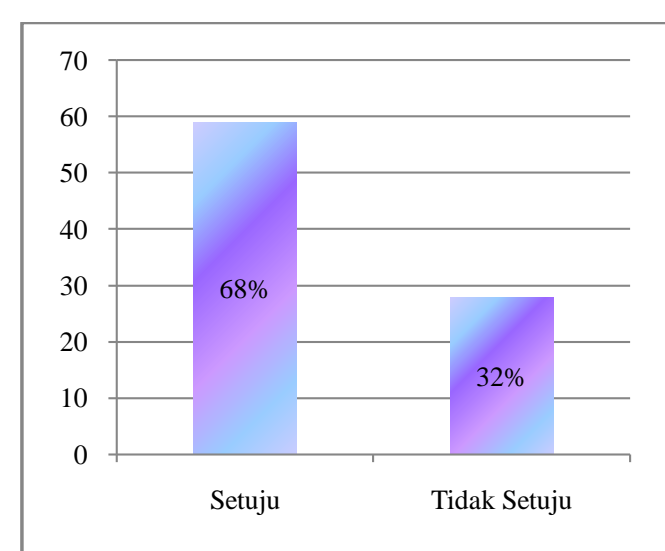

Gambar 24. Distribusi frekuensi berdasarkan pertanyaan nomor 8

Gambar 24 menunjukan 68\% atau 59 responden menjawab setuju merasa tegang atau takut jika melihat peralatan pada ruang praktek dokter gigi sedangkan 32\% atau 28 responden menjawab tidak setuju.

i. Distribusi frekuensi berdasarkan pertanyaan nomor 9 (perasaan takut dan tegang kadang menjadi pertimbangan untuk membatalkan pergi ke dokter gigi)

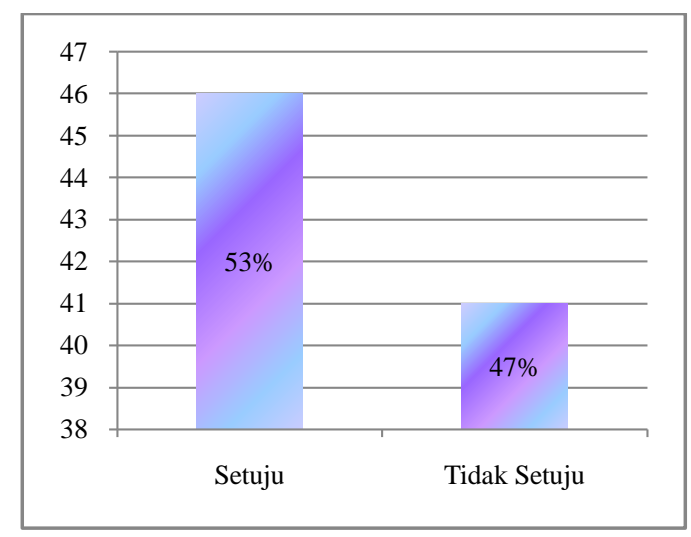

Gambar 25. Distribusi frekuensi berdasarkan pertanyaan nomor 9

Gambar 25 menunjukan bahwa sebanyak $53 \%$ atau 46 responden menjawab setuju, sedangkan $47 \%$ atau 41 responden menjawab tidak setuju.

j. Distribusi frekuensi berdasarkan pertanyaan nomor 10 (responden berpikir bahwa gigi tidak teratur dan rusak 
merupakan suatu nasib, jadi tidak perlu dilakukan pencabutan gigi)

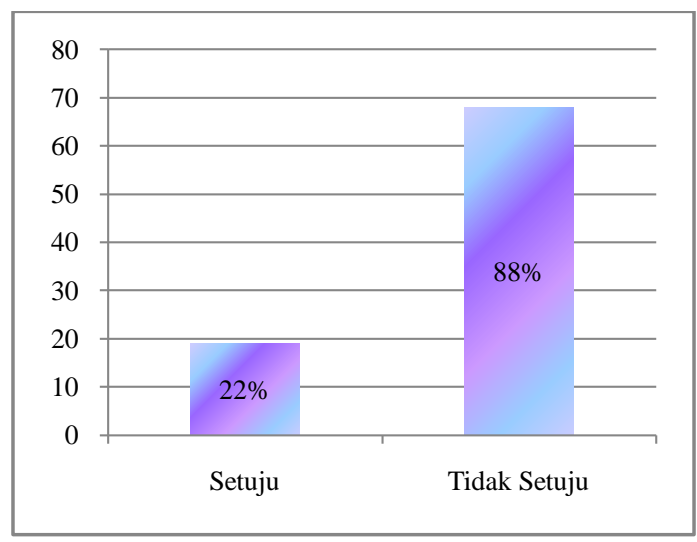

Gambar 26. Distribusi frekuensi berdasarkan pertanyaan nomor 10

Berdasarkan gambar 26 terlihat 88\% atau 68 responden merupakan persentase tertinggi tidak setuju bahwa gigi yang tidak teratur dan rusak adalah suatu nasib jadi tidak perlu dilakukan pencabutan dan sisanya $22 \%$ atau 19 responden menjawab setuju.

\section{BAHASAN}

\section{Pengetahuan}

Hasil penelitian menunjukan sebanyak 34 responden (39\%) yang mengetahui bahwa pemeriksaan kesehatan gigi dan mulut ke dokter gigi atau puskesmas secara rutin dilakukan setiap 6 bulan sekali. Hal ini karena masih kurangnya dilakukan penyuluhan tentang kesehatan gigi dan mulut di desa Molompar Utara sehingga masih sedikit yang mengetahui tentang kontrol rutin ke dokter gigi. Hasil ini tidak berbeda jauh dengan hasil penelitian yang dilakukan oleh Alamsyah pada tahun 2010 di Kelurahan Sari Rejo Medan yang menunjukan $41 \%$ responden yang menjawab tidak tahu dan 33\% menjawab tahu. ${ }^{17}$

Hasil penelitian sebanyak 40 responden (46\%) yang mengetahui bahwa pada penderita penyakit jantung tidak boleh dilakukan pencabutan gigi. Hasil tersebut masih menunjukkan bahwa para responden tidak memiliki wawasan yang luas sehingga masih belum mengetahui penyakit apa saja yang tidak boleh dilakukan pada saat pencabutan gigi. Hal ini sama dengan penelitian yang dilakukan oleh Morgan pada tahun 2012 di Kota Tomohon sebesar $72,92 \%$ tidak mengetahui bahwa pencabutan gigi tidak boleh dilakukan pada penderita penyakit jantung. ${ }^{18}$

Penelitian tentang tahu atau tidaknya responden terhadap pencabutan gigi yang tidak boleh dilakukan pada penderita penyakit gula atau diabetes. Didapati hanya sebanyak 30 responden (34\%) yang mengetahui hal tersebut. Pengetahuan ini masih kurang karena para responden kurang mencari tahu informasi-informasi dari berbagai media cetak maupun elektronik. Dalam hal ini distribusi responden berdasarkan usia yang paling banyak masih berusia $17-27$ tahun. Hasil tersebut memperlihatkan masih banyak masyarakat yang belum mengetahui bahwa di bidang kedokteran gigi, penderita dengan diabetes melitus yang tidak terkontrol akan mempunyai resiko infeksi dan penyembuhan luka yang buruk. Oleh sebab itu, sosialisasi tentang penyakit-penyakit yang membahayakan pencabutan gigi perlu dilakukan, agar supaya pengetahuan dibidang kedokteran gigi akan lebih banyak diketahui oleh masyarakat. $^{19}$

Demikian halnya dengan pencabutan gigi yang tidak boleh dilakukan pada penderita darah tinggi atau hipertensi. Diperoleh sebanyak 41 responden (47\%) yang mengetahui hal tersebut. Pengetahuan tentang pencabutan gigi pada penyakit yang membahayakan pada pencabutan gigi masih kurang. Oleh sebab itu perlu dilakukan penyuluhan dan sosialisasi tentang pencabutan gigi pada penyakit-penyakit berbahaya tersebut. $^{5}$

Gigi palsu dapat menggantikan gigi yang hilang akibat pencabutan gigi. Pada penelitian ini diperoleh sebanyak 50 responden (57\%) yang mengetahui perawatan setelah mencabut gigi bisa dengan pemasangan gigi palsu. Hal ini sudah cukup baik karena lebih dari setengah jumlah responden yang mengetahui pernyataan tersebut. Berdasarkan Riskesdas 2007 prevalensi penduduk yang mempunyai masalah gigi dan mulut yaitu 22,6\% dengan presentase pemasangan gigi tiruan $10,3 \%{ }^{2}$

Berdasarkan hasil penelitian, hanya diperoleh sebanyak 12 responden (14\%) yang mengetahui pencabutan pada gigi yang miring atau impaksi dilakukan dengan operasi yang disebut odontektomi. Hal ini menunjukkan masih sedikit responden yang mengetahuinya. Hasil ini dapat dihubungkan dengan penelitian yang dilakukan oleh Adisti Dwipayanti dan Winny Adriatmoko di bagian 
bedah mulut Universitas Negeri Jember selama bulan April sampai Juni 2005, dalam penelitian menunjukkan dari 63 penderita odontektomi terdapat 24 penderita usia 20-21 tahun atau komplikasi post odontektomi terbanyak pada usia muda yaitu 28,6\%. Sehingga dalam penelitian tersebut disimpulkan sebagian besar penderita impaksi berada pada usia muda. Hal ini dapat menjadi dasar bahwa pengetahuan siswa SMA tentang impaksi gigi sangat penting untuk diketahui karena usia muda merupakan kelompok yang dominan terjadinya impaksi. ${ }^{21}$

Selanjutnya pada penelitian tentang responden yang mengetahui pencabutan gigi yang rusak sebaiknya dicabut dari pada membiarkan, diperoleh sebanyak 67 responden (77\%) yang mengetahuinya. Hal ini karena kebanyakan kasus pencabutan gigi dilakukan karena gigi tersebut sudah tidak bisa dirawat lagi dan menyebabkan kesakitan sehingga menjadi alasan para responden untuk mencabut gigi. ${ }^{3}$

Pencabutan gigi membantu menjaga kesehatan mulut diketahui sebanyak 74 responden (85\%). Hal ini berhubungan dengan pencabutan gigi yang sudah rusak mengganggu kesehatan gigi dan mulut dengan menjadi tempat perkembangbiakan bakteri, sehingga pencabutan gigi tersebut membantu menjaga kesehatan mulut. Hal ini telah dipahami bahwa membiarkan gigi yang rusak didalam mulut akan menyebabkan lebih parah lagi rasa sakit yang mereka derita, menimbulkan bau busuk dalam mulut dan dapat mengurangi nafsu makan. ${ }^{22}$

Sebanyak 56 responden (64\%) mengetahui bahwa biaya pencabutan gigi relatif murah. Sisanya sebanyak 31 responden (36\%) tidak mengetahui hal tersebut. Hal ini dikarenakan masih belum semua masyarakat desa Molompar pernah berkunjung ke dokter gigi atau puskesmas sehingga belum mengetahui biaya pencabutan gigi yang relatif murah di puskesmas. Hasil penelitian ini sama dengan penelitian yang dilakukan oleh Astiana Indah Wiguna di Kecamatan Enrekang Sulawesi Selatan pada tahun 2007, bahwa umumnya setuju biaya pencabutan gigi yang dikeluarkan saat datang ke puskesmas relative murah dan terjangkau. ${ }^{1}$

Sebanyak 77 responden (88\%) mengetahui bahwa untuk melakukan pencabutan gigi lebih baik ke puskemas daripada menggunakan cara tradisional.
Sebanyak 10 orang (12\%) tidak mengetahuinya karena masih terbiasa dengan cara tradisional. Umumnya responden yang lebih memilih cara tradisional ialah masyarakat yang berumur diatas 50 tahun, menganggap cara tradisional lebih cepat dan mudah dilakukan serta tidak mengeluarkan biaya. $^{23}$

\section{Sikap}

Hasil penelitian menunjukkan sebanyak 53 responden (60\%) merasa cemas ketika akan mencabut gigi. Responden yang merasa cemas tersebut pada umumnya belum pernah mencabut gigi sehingga ketakutannya berasal dari sugesti orang-orang disekitarnya yang mengatakan bahwa mencabut gigi itu menakutkan. Sisanya sebanyak 34 responden (40\%) sebagian besar sudah pernah mencabut gigi sehingga tidak takut lagi untuk mencabut gigi.

Responden sebanyak 82 orang (94\%) menyatakan akan pergi ke dokter gigi atau puskesmas apabila giginya berlubang. Sisanya sebanyak 5 responden (6\%) lebih memilih untuk tidak langsung ke dokter gigi apabila giginya berlubang dan menunggu sampai gigi tersebut sakitnya tidak tertahankan lagi.

Sebanyak 73 responden (84\%) merasa malu apabila giginya yang rusak terlihat oleh lawan bicara. Masyarakat Desa Molompar sering melakukan interaksi sosial sehingga mereka berpikir kesan estetik itu penting dan harus dipertahankan. Pada penelitian ini disebabkan kurangnya penyuluhan kesehatan gigi dan beberapa penderita juga sering menunda-nunda ke poliklinik gigi atau puskesmas.

Sebanyak 46 responden (53\%) setuju untuk mempertimbangkan pendapat orang disekitarnya mengenai pencabutan gigi. Beberapa responden merasa ragu untuk ke dokter gigi atau puskesmas saat gigi bermasalah apalagi saat gigi perlu dicabut. Pendapat dan saran orang disekitar yang meyakinkan bahwa responden memerlukan pencabutan gigi sangat mempengaruhi sikap responden untuk pergi ke dokter gigi/ puskesmas.

Sebanyak 68 responden (78\%) yang pergi ke dokter gigi ingin segera mencabut giginya. Hal ini disebabkan untuk pergi ke dokter gigi/puskesmas, responden cenderung menunggu sampai gigi sudah sangat rusak sehingga tindakan yang dilakukan adalah 
mencabut gigi. Apabila ada alternatif tindakan lain yang bisa dilakukan, sebagian besar responden memilih untuk tetap dilakukan pencabutan dengan alasan tidak ingin sakit gigi lagi.

Jenis pencabutan gigi yang akan dilakukan diserahkan kepada dokter gigi, sebanyak 73 responden (84\%) menyetujui pemilihan jenis pencabutan gigi diserahkan kepada dokter gigi. Responden lebih mempercayai dokter gigi sebagai pihak yang lebih mengetahui untuk jenis pencabutan gigi yang akan dilakukan.

Responden sebanyak 85 orang (98\%) merasa sehat dan nyaman apabila gigi yang bermasalah telah dicabut. Hal ini karena responden tidak akan merasakan keluhankeluhan karena gigi berlubang yang mengakibatkan timbulnya rasa sakit yang mengganggu.

Saat melihat peralatan pada ruang praktek dokter gigi ada sebanyak 59 responden (68\%) yang merasa tegang atau takut. Peralatan kedokteran gigi umumnya terlihat tajam dan menakutkan sehingga pasien yang berobat ke dokter gigi merasa tegang atau takut apabila akan melakukan perawatan gigi dan mulut sehingga sebanyak 46 responden (53\%) memiliki pertimbangan untuk membatalkan pergi ke dokter gigi.

Hasil penelitian menunjukkan hanya sebanyak 19 responden (22\%) yang berpikir bahwa gigi yang tidak teratur dan rusak merupakan nasib sehingga tidak perlu dilakukan pencabutan. Sebagian besar responden yaitu sebanyak 68 orang (78\%) yang merasa bahwa gigi yang tidak teratur atau rusak perlu dilakukan pencabutan. Dari penelitian yang dilakukan kebanyakan masyarakat Molompar Utara akan pergi ke puskesmas apabila gigi berlubang, dikarenakan biaya pengobatan lebih murah dan akses yang mudah dijangkau. Sebagian masyarakat masih ada juga yang menunggu sampai giginya sakit untuk datang berobat ke puskesmas. Kurangnya pengetahuan masyarakat tentang perawatan gigi terbaru membuat masyarakat lebih memilih gigi yang rusak langsung dicabut. Alasan lain juga masyarakat menganggap pencabutan gigi lebih cepat menyelesaikan masalah Disamping itu biaya pencabutan gigi yang murah menjadi alasan masyarakat. Ini yang mengakibatan masyarakat cenderung lebih memilih datang ke puskesmas dibandingkan ke praktek dokter gigi. Ketika pengetahuan masyarakat bertambah maka akan mengubah sikap masyarakat tentang perawatan gigi. Ini dikarenakan pola pikir manusia yang semakin berkembang dan terbuka terhadap kemajuan teknologi dibidang kesehatan. ${ }^{24}$

\section{SIMPULAN}

Berdasarkan hasil penelitian didapatkan tingkat pengetahuan dan sikap masyarakat di Desa Molompar Utara tergolong baik.

\section{SARAN}

\section{Bagi pemerintah}

Perlu diadakan penyuluhan kesehatan serta melengkapi fasilitas kesehatan khususnya tenaga kesehatan Dokter Gigi supaya bisa menambah pengetahuan serta mengubah sikap masyarakat di Desa Molompar Utara secara umum tentang kesehatan gigi dan mulut.

\section{Bagi masyarakat}

Perlu upaya peningkatan sistem informasi tentang pengetahuan dan sikap masyarakat terhadap pencabutan gigi, baik melalui media cetak maupun elektronik.

\section{Bagi mahasiswa}

Diharapkan menjadi barometer kualitas pengetahuan dan sikap masyarakat tentang pencabutan gigi, serta menyusun konsep penyuluhan yang lebih baik lagi dan dapat dilakukan penelitian lebih lanjut tentang tingkat pengetahuan pencabutan gigi serta hubungannya dengan sikap masyarakat secara umum.

\section{DAFTAR PUSTAKA}

1. Wiguna A I. Hubungan Sikap dan Pengetahuan Masyarakat Tentang Pencabutan Gigi. SKRIPSI. FKG Universitas Hasanuddin; Makassar. 2011

2. RISKESDAS. Laporan Hasil Riset Kesehatan Dasar. Laporan Hasil Riset Kesehatan Dasar.2007

3. Anonymous. Dentistry Molar. Perdarahan Pasca Ekstrasi Gigi, Penegahan dan Penatalaksanaannya. [online]. (diakses 26 februari 2013) tersedia dari URL:http//www.dentistrymolar.wordpres s.com/2011/03/02/Perdarahan-pascaekstrasi-gigi-pencegahan-danpenatalaksanaannya

4. Arwana AJ. Tindakan Ekstrasi Gigi Pada Pasien Dengan Penyulit Penyakit 
Sistemik. Majalah PABMI. 2007;10(1) : 1-7s

5. Yuliana RC, dkk. Survei Pola Pengobatan Masyarakat Penggunaan Obat Tradisional Dari Bahan Tumbuhan di Kabupaten Oku Tahun 2006. h. 61

6. Alamsyah RM. Need Pemeriksaan dan Perawatan Gigi Pada Ibu-ibu di Kelurahan Sari Rejo Kecamatan Medan Polonia Kotamadya Medan 2009 [Skripsi]. Medan: FKG USU, 2010.

7. Rambing M. Gambaran Tingkat Pengetahuan Siswa SMA Tentang Pencabutan Gigi di Kota Tomohon. SKRIPSI. PSKG Universitas Sam Ratulangi. Manado. 2012

8. Lely SMA, T indirawati. Pengaruh Kadar Glukosa Darah Terkontrol Terhadap Penurunan Derajat Kegoyahan Gigi Penderita Diabetes Mellitus di RS Persahabatan Jakarta. Media Litbang Kesehatan. 2004; 14(3): 38-42.
9. Dwipayanti A, Adriatmoko W, Rochim A. Komplikasi Post Odontektomi Gigi Molar Ketiga Rahang Bawah Impaksi. Jurnal PDGI. 2009; 58(2) : 20-4.

10. Natamiharja L, Hayana NB. Abrasi Gigi Berdasarkan Umur, Pendidikan, Perilaku Menyikat Gigi Pada Ibu-ibu di Kelurahan Air Jamban Kecamatan Mandau, Duri-Riau. Dentika Dental Journal. 2009;14(1): 43-7.

11. Dwiatmoko S, Kristiana D. Pengaruh Komunikasi Kesehatan Secara Lisan dan Tulisan Terhadap Pengetahuan, Sikap dan Kebersihan Gigi Tiruan Para Pemakai Gigi Tiruan Lepasan. Dentika Dental Journal. 2011;16(1): 14-7.

12. Okawa $\mathrm{K}$, Ichinohe $\mathrm{T}$, Kaneko $\mathrm{Y}$. Anxiety may enhance pain during dental treatment, Bull Tokyo Dent Coll; August 2005: 